\title{
Steer nutritional response to intensive-early stocking on shortgrass rangeland
}

\author{
KENNETH C. OLSON, JOHN R. JAEGER, JOHN R. BRETHOUR, AND THOMAS B. AVERY
}

Authors are former Associate Professor, former Research Assistant, and Professor, Agricultural Research Center-Hays, Kansas State Univ., 1232 240 Avenue, Hays, Kans. 67601-9228, and Professor (deceased), College of Vet. Med., Kansas State Univ., Manhattan, Kans. 66506. Olson is currently Associate Professor, Animal, Dairy, and Veterinary Sciences Dept., Utah State Univ., Logan, Utah 84322-4815. Jaeger is currently Research Assistant, Eastern Oregon Agricultural Research Center, Oregon State Univ., Union, Ore. 97883.

\section{Abstract}

Steer nutritional response to vegetation conditions created by 4 grazing treatments was evaluated during the final 2 years (1987-88) of a 9-year grazing trial. Treatments were season-long stocking (treatment 1 ) at a moderate stocking rate and intensiveearly stocking at 3 stocking rates: equal to season-long stocking by using twice as many steers for the first half of the season-long stocking grazing season (double-stocked-intensive-early stocking, treatment 2), and 2 rates greater than season-long stocking made by stocking at 2.5 or 3 times the stocking density of season-long stocking (2.5X- and triple-stocked-intensive-early stocking, treatments 3 and 4). Each treatment was replicated twice in a randomized-complete block. Three esophageally fistulated steers were placed in each pasture to collect diet samples for nutritional analyses, including crude protein and cell wall constituents. Total feces were collected from 3 steers in each pasture to estimate fecal output and calculate forage intake. Diet digestibility was estimated using alkaline-peroxide lignin as an internal marker. Three or 4 sampling periods were conducted during each grazing season. Herbage availability and dietary crude protein were similar among treatments in 1987, but both declined as stocking density increased in 1988. Cell wall constituents generally increased as stocking density increased in 1987 , but were similar among treatments in 1988. Digestibility and forage intake were unaffected by grazing treatments in both years. Steer average daily gain declined as stocking density increased in both years. Seasonal changes in diet quality and forage intake reflected the precipitation pattern with improved nutrition whenever precipitation caused growth of the warm-season shortgrasses. Nutrient intake was reduced by stocking rates greater than that employed under season-long stocking, but was generally similar between seasonlong stocking and double-stocked-intensive-early stocking.

Key Words: grazing systems, beef cattle, stockers, diet quality, forage intake

Intensive-early stocking is a grazing management practice intended to improve efficiency of converting vegetation to livestock products while sustaining the natural resource. Under intensive-early stocking, stocker cattle are placed on rangeland in the spring at double the number recommended for season-long stocking, but removed at the midpoint of the season-long stocking grazing season. The result is doubled stocking density (animal

Contribution 98-214-J from the Kansas Agricultural Experiment Station.

The authors thank H. Jansonius for technical assistance.

Manuscript accepted 7 Sept. 01.
Resumen

La respuesta nutricional de novillos a condiciones de vegetación creadas por 4 tratamientos de pastoreo fue evaluada durante los últimos dos años (1987-88) de una prueba de pastoreo que duro 9 años. Los tratamientos fueron uno de temporada larga (SLS, por sus siglas en inglés, tratamiento 1) con carga animal moderada y otro con carga animal intensiva temprana (IES por sus siglas en inglés), a tres rangos de carga animal: igual a SLS, usando el doble de novillos para la primera mitad de la temporada de pastoreo SLS (2X-IES, tratamiento 2), y dos rangos mayores que SLS compuestos por 2.5 o 3 veces la densidad de carga animal de SLS (2.5X- y 3X-IES, tratamientos 3 y 4). Cada tratamiento fue repetido dos veces en un bloque completo al azar. Tres novillos fistulados vía esofágica fueron puestos en cada lugar de pastoreo para recolectar muestras para análisis nutricional, incluyendo proteína cruda y constituyentes de pared celular. Heces totales fueron recolectadas de tres novillos en cada lugar para estimar la descarga fecal y calcular el consumo de forraje. La digestibilidad de la dieta fue estimada usando lignina peroxido-alcalina como un marcador interno. Tres o cuatro periodos de muestra fueron conducidos durante cada estación de pastoreo. La disponibilidad de pasto y de proteína cruda dietética fueron similares entre los tratamientos en 1987, pero ambos declinaron conforme la densidad de ganado incrementó en 1988. Los constituyentes de pared celular generalmente se incrementaron conforme la densidad de ganado incrementó durante 1987, pero fueron similares entre tratamientos en 1988. La digestibilidad y el consumo de forraje no fueron afectados por los tratamientos de pastoreo en ambos años. La ganancia de peso diaria promedio (ADG por sus siglas en inglés) de los novillos declinó conforme la densidad de ganado se incrementó en ambos años. Cambios estacionales en la calidad de la dieta y el consumo de forraje reflejaron el patrón de precipitación con nutrición mejorada cada vez que la precipitación provocó el crecimiento de los zacates cortos de temporada cálida. El consumo de nutrientes se redujo por los rangos de ganado mayores que el empleado bajo SLS, pero fue generalmente similar entre SLS y $2 X$-IES.

units $\mathrm{ha}^{-1}$ ) during the grazing season, but a stocking rate [animal unit-months (AUM) ha ${ }^{-1}$ ] equivalent to season-long stocking. The purposes are to concentrate grazing during the period of highest nutritional quality of the forage, thus increasing livestock production, and to allow a late-season rest so that desirable species enter the dormant season in high vigor. Although this practice is highly successful at increasing livestock production and improving vegetation at up to 3 times the number of cattle recommended for 
season-long stocking on tallgrass prairie (Owensby et al. 1988, McCollum et al. 1990), we reported that intensive-early stocking only maintained steer performance and vegetation characteristics at double-stocked-intensive-early stocking, and both responses decreased at triplestocked-intensive-early stocking on shortgrass plains (Olson et al. 1993).

During the final 2 years of a long-term experiment comparing intensive-early stocking to season-long stocking (Olson et al. 1993), we evaluated steer nutritional responses to pasture conditions created by the intensive-early stocking grazing treatments. The objective was to compare dietary nutritional quality and forage intake by steers among season-long stocking, double-stocked-intensive-early stocking, 2.5X-intensive-early stocking, and triple-stocked-intensive-early stocking. Our hypothesis was that nutrient intake would decline at higher stocking rates of intensive-early stocking (2.5X- and triplestocked-intensive-early stocking) based on previously observed reductions in animal performance and herbage biomass.

\section{Materials and Methods}

\section{Study Site}

The study was conducted on the Kansas State University Agricultural Research Center-Hays, located in west-central Kansas $\left(38.9^{\circ} \mathrm{N} 99.3^{\circ} \mathrm{W}\right)$. The climate is semiarid with a long-term mean annual precipitation of $571 \mathrm{~mm}$, of which $77 \%$ occurs during April through September. Annual precipitation was 687 and $363 \mathrm{~mm}$ in 1987 and 1988, respectively. These amounts were 120 and $64 \%$ of average, respectively. Monthly precipitation was above average in most months of 1987 and below average in most months of 1988 , especially before and during the growing season (Fig. 1).

The vegetation was typical of shortgrass plains. Dominant species were western wheatgrass [Pascopyrum smithii (Rydb.) Löve], buffalograss [Buchloe dactyloides (Nutt.) Engelm.l, and blue grama [Bouteloua gracilis (HBK.) Lag. ex Steud.]. Subdominant species were Japanese brome (Bromus japonicus Thunb.) and western ragiveed (Ambrosia psilostachya DC.). Olson et al. (1993) described the study area in detail.

\section{Grazing Treatments}

The original study was initiated in 1980 and continued through 1988. At initiation of the trial, 4 grazing treatments were

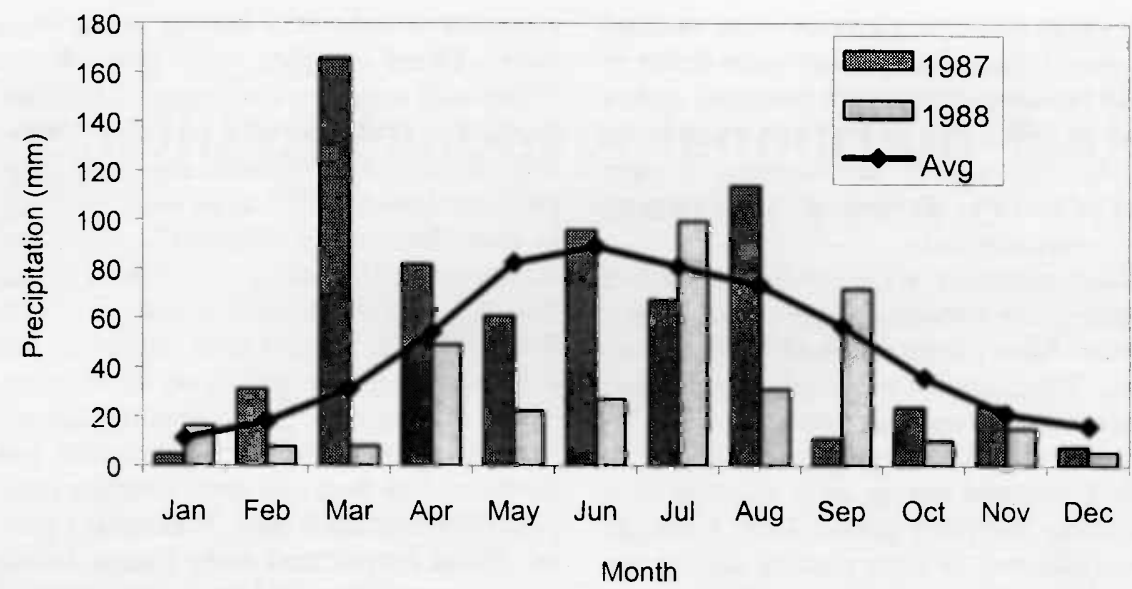

Fig. 1. Monthly precipitation during each year of study and long-term mean monthly precipitation.

assigned to 8 pastures in a randomizedcomplete-block design with 2 blocks. The blocking factor was range site composition in the pastures. Each treatment remained on the same pastures throughout the study. The control was season-long stocking at 1.4 ha steer $^{-1}$ for a 5-month grazing season (1 May to 1 Oct.). Previous long-term research indicated this stocking rate was sustainable on this site (Launchbaugh 1957). The second and third treatments were intensive-early stocking at 2 stocking densities, 0.7 ha steer ${ }^{-1}$ for doublestocked-intensive-early stocking and 0.5 ha steer ${ }^{-1}$ for triple-stocked-intensive-early stocking, for a 2.5-month grazing season (1 May to 15 July). Double-stocked intensive-early stocking yielded a stocking rate equal to season-long stocking ( 0.4 ha $\mathrm{AUM}^{-1}$ ) and triple-stocked-intensive-early stocking yielded a stocking rate of 0.28 ha $\mathrm{AUM}^{-1}$. The fourth treatment from initiation of the original grazing trial through 1983 was triple-stocked-intensive-early stocking supplemented daily with $1.8 \mathrm{~kg}$ of sorghum grain. This was in addition to the triple-stocked-intensive-early stocking treatment that was not supplemented. It was apparent by 1984 that triple-stockedintensive-early stocking was not sustainable, so the supplemented triple-stockedintensive-early stocking treatment was changed to $2.5 \mathrm{X}$-intensive-early stocking (ivithout supplement) from 1984 through 1988 to evaluate a stocking rate between double-stocked- and triple-stocked-intensive-early stocking. The $2.5 \mathrm{X}$-intensiveearly stocking treatment yielded a stocking density of 0.6 ha steer ${ }^{-1}$ and a stocking rate of 0.33 ha $\mathrm{AUM}^{-1}$. Thus, the 4 grazing treatments used from 1984 through the experiment reported herein were seasonlong stocking, double-stocked-intensiveearly stocking, $2.5 \mathrm{X}$-intensive-early stocking, and triple-stocked-intensive-early stocking. Pastures were 12.5 ha (block 1) or 14.6 ha (block 2), so steer numbers per pasture were 9 or 10,18 or 20,23 or 25 , and 27 or 31 for blocks 1 or 2 of seasonlong stocking, double-stocked-intensiveearly stocking, $2.5 \mathrm{X}$-intensive-early stocking, and triple-stocked-intensive-early stocking, respectively. Grazing was initiated on 30 Apr. 1987 and 28 Apr. 1988. Intensive-early stocking was terminated on 16 Jul. 1987 and 29 Jun. 1988, and season-long stocking was terminated on 2 Oct. 1987 and 7 Sept. 1988. Both intensive-early stocking and season-long stocking grazing seasons were shortened in 1988 because drought limited forage.

\section{Experimental Livestock}

Yearling steers ( 12 to 14 months of age) of British breeding (Hereford or Hereford $\times$ Angus) with mean initial weights of 308 and $342 \mathrm{~kg}$ were used in 1987 and 1988 , respectively. Twenty-four contemporaries of the 1987 steers were tamed and esophageally fistulated in Mar. 1987. Three fistulated steers were assigned randomly to each treatment pasture as part of each treatment group described above. The same fistulated steers were used as 2year-olds in 1988 rather than fistulate a new group of steers. Steers had continuous ad-libitum access to water and salt throughout the experiment. Steers that were not fistulated or used for fecal collections (see below) were weighed after a 16 to 18 hour fast at initiation of grazing and termination of intensive-early stocking grazing to calculate average daily gain (ADG).

\section{Data Collection and Analysis}

Nutritional sampling was conducted in 4 and 3 periods in 1987 and 1988, respectively, during the early-summer period that both season-long stocking and inten- 
sive-early stocking pastures were stocked (Table 1). Sampling periods were fewer in 1988 because steers were removed earlier than in 1987. Sampling was conducted during 3 periods in late summer of each year when only season-long stocking pastures were stocked.

Diet samples were collected from esophageally fistulated steers shortly after sunrise. Steers were not fasted before sampling. Two samples were collected in each pasture during most sampling periods. To accomplish this, samples were collected in 2 to 4 pastures during each morning of a weeklong sampling period. Only 1 sample was collected in each pasture during the first 3 sampling periods of 1988 because of labor constraints. Samples were frozen immediately after collection and stored frozen until freeze-dried. Dried samples were ground in a Wiley mill to pass a 1$\mathrm{mm}$ screen. Ground samples were analyzed for dry and organic matter (DM and OM, AOAC 1984). Crude protein (CP) was determined as Kjeldahl N (AOAC 1984) $\times 6.25$. Neutral and acid detergent fiber (NDF and ADF) and acid detergent lignin (ADL) were determined using the non-sequential procedures of Goering and Van Soest (1970), except sodium sulfite and decahydronapthalene were eliminated from the NDF and ADF extractions and asbestos was eliminated from the ADL extraction. Hemicellulose was calculated as the difference between NDF and ADF, and cellulose was calculated as the percentage weight loss during incubation in $72 \% \mathrm{H}_{2} \mathrm{SO}_{4}$. All results were converted to an $\mathrm{OM}$ basis.

Forage intake was estimated by fecal output/diet indigestibility. Fecal output was estimated using total fecal collections. Each year, 24 intact yearling steers were tamed and trained to wear fecal bags. Thus, 3 trained steers were assigned randomly to the treatment group in each pasture. Feces were collected in all sampling periods except the first in 1987. Feces were collected for 4 consecutive days during each sampling period. Fecal bags were changed once daily. Each daily fecal collection was weighed and sampled. Samples were stored frozen until dried to a

Table 1. Periods when nutritional sampling was performed.

\begin{tabular}{lccc}
\hline \hline & Period & 1987 & 1988 \\
\hline Season-long & 1 & $11-19$ May & $2-6$ May \\
stocking and & 2 & $1-12$ Jun. & $23-27$ May \\
intensive-early & 3 & $22-26$ Jun. & $13-17$ Jun. \\
stocking & 4 & $6-10$ Jul. & \\
Season-long & 1 & $3-7$ Aug. & $11-15$ Jul. \\
stocking only & 2 & 31 Aug.-4 Sep. & $1-5$ Aug. \\
& 3 & 28 Sep.-2 Oct. & 29 Aug.-2 Sept \\
\hline
\end{tabular}

constant weight in a forced air oven at $60^{\circ} \mathrm{C}$. Dried samples were ground in a Wiley mill to pass a 1-mm screen and analyzed for DM and OM (AOAC 1984). Digestibility was estimated using alkalineperoxide lignin (APL) as an internal marker according to the PRE-APL procedure described by Cochran et al. (1988), except that $0.5 \mathrm{~g}$ rather than $1 \mathrm{~g}$ samples were used. The technique was validated for native range forage grown on the research center in a separate experiment (Olson and Sunvold 1991). The APL procedure was performed on feed and fecal samples composited within each steer $\times$ sampling period. Fecal output and daily forage intake were expressed as $\mathrm{OM}$ on a percentage of body weight $(\mathrm{BW})$ basis.

Total herbage availability was estimated using a disk meter (Sharrow 1984, Karl and Nicholson 1987) in a double-sampling procedure. Each pasture was sampled except the first in 1988. Sampling involved measuring disk height at 25 locations in each pasture and clipping every fifth plot. Plots were clipped at ground level and all plant material from each plot was placed in a bag. Samples were dried to a constant weight in a $100^{\circ} \mathrm{C}$ oven. We evaluated the best predictive relationship between disk meter height and sample weight based on scatter plots of height versus weight and regression statistics from various regression relationships. Including grazing treatment as a class effect in an analysis of covariance approach indicated that the relationship between weight and height did not vary among grazing treatments. However, when date of sampling was included as a class effect, results indicated that intercept and slope both varied among dates. Consequently, we developed separate regressions for each sampling period by regressing weight on the natural log of height. R-squared values ranged from 0.68 to 0.90 in 1987 and 0.67 to 0.83 in 1988 . Plot weights were then predicted from height readings and converted to $\mathrm{kg} \mathrm{ha}^{-1}$ for subsequent statistical analysis. during each nutritional sampling period

\section{Statistical Analysis}

All dependent variables were analyzed using the General Linear Models procedure of the Statistical Analysis System (SAS 1988). Pasture was the experimental unit for all analyses. Data were analyzed separately for each year because of the different number of sampling periods. Nutritional data collected while animals were in season-long stocking and intensive-early stocking treatments were analyzed using a randomized-complete block design with a split-plot treatment structure. Grazing treatment was in the main plot with block $X$ treatment used as the error term. Sampling period and grazing treatment $X$ sampling period were in the subplot with the residual used as the error term. To evaluate changes over time throughout the entire season-long stocking grazing season (particularly during the period when intensive-early stocking treatments were not grazed), data from the season-long stocking treatment were used in a randomized-complete block design with sampling period as the main effect. To evaluate steer performance during these 2 years of the overall performance trial (Olson et al. 1993), ADG was analyzed using a randomized-complete block design with a split-plot treatment structure. Year was in the main plot and block $X$ year was the error term. Grazing treatment and year $X$ grazing treatment were in the subplot with the residual used as the error term. Least squares means and standard errors for split-plot designs were calculated (Cochran and Cox 1957). Following significant $\mathrm{F}$ tests, main effect means were separated using single-degree-of-freedom contrasts. Contrasts were pair-wise comparisons of all possible grazing treatment pairings. When grazing treatment and sampling period interacted, grazing treatment means were separated within each sampling period using the same contrasts. Grazing treatment and sampling period rarely interacted, so only significant interactions are indicated herein. All tests were considered significant at $\mathrm{P} \leq 0.10$.

\section{Results and Discussion}

Herbage availability did not vary among grazing treatments in $1987(\mathrm{P}=0.25$, Table 2), but decreased as stocking rate increased in $1988(\mathrm{P}=0.08)$. Numeric differences among grazing treatments were large in 1987, with the triple-stockedintensive-early stocking mean being only $60 \%$ of the season-long stocking mean in Table 2. However, large variability and 
limited replication among experimental units precluded the power to statistically detect differences. We (Olson et al. 1993) previously reported that plant species composition shifted from mixed grass to shortgrass domination and herbage biomass decreased as stocking rate increased during the entire 9 years of this grazing study. The difference in species composition and herbage availability among grazing treatments was visually apparent. Herbage availability increased $(\mathrm{P}<0.01)$ from May through July during 1987 (Table 2), and then declined $(\mathrm{P}<0.01)$ during September in the season-long stocking treatment (Table 3 ). This pattern reflected the above-average precipitation (Fig. 1) and good growing conditions experienced during the growing season of 1987. Herbage availability declined $(\mathrm{P}<$ $0.01)$ during intensive-early stocking grazing in 1988 (Table 2), and then was similar across sample periods in the seasonlong stocking treatment during July and August (Table 3). Drought severely reduced herbage availability during 1988 , particularly during the intensive-early stocking season. Above-average precipitation during July 1988 stabilized herbage availability during July and August.

During 1987, dietary crude protein displayed a grazing treatment $X$ sampling period interaction $(P=0.03$, Table 6$)$. The interaction occurred because crude protein did not vary among grazing treatments during the first 2 sampling periods, but varied during the last 2 . Dietary crude protein was higher under double-stockedintensive-early stocking than the other 3 treatments during the third sampling period, and was higher under double-stockedand triple-stocked-intensive-early stocking than season-long stocking and 2.5X-intensive-early stocking during the fourth sampling period. Dietary crude protein did not change during August and early September under season-long stocking, but declined by the end of the season-long stocking grazing season $(\mathrm{P}<0.01$, Table 3 ). During 1988 , dietary crude protein declined with increasing stocking density $(\mathrm{P}=0.02$, Table 4$)$ and with advancing time $(\mathrm{P}<0.01$, Table 5$)$. Dietary crude protein rebounded and then declined again during late summer under season-long stocking $(\mathrm{P}<0.01$, Table 3$)$. Dietary crude protein was similar to that reported by Vavra et al. (1973) for shortgrass rangeland and Wallace et al. (1972) for sandhills rangeland, both in eastern Colorado, but was slightly less than that reported by McCollum et al. (1985) for shortgrass rangeland in eastern New Mexico. Vavra

Table 2. Herbage biomass $\left(\mathrm{kg} \mathrm{ha}^{-1}\right)$ available during each year under season-long stocking (SLS) or intensive-early stocking (IES) at $2,2.5$, or 3 times the stocking density of SLS (2X, 2.5X, or $3 \mathrm{X}$, respectively) and during each sampling period.

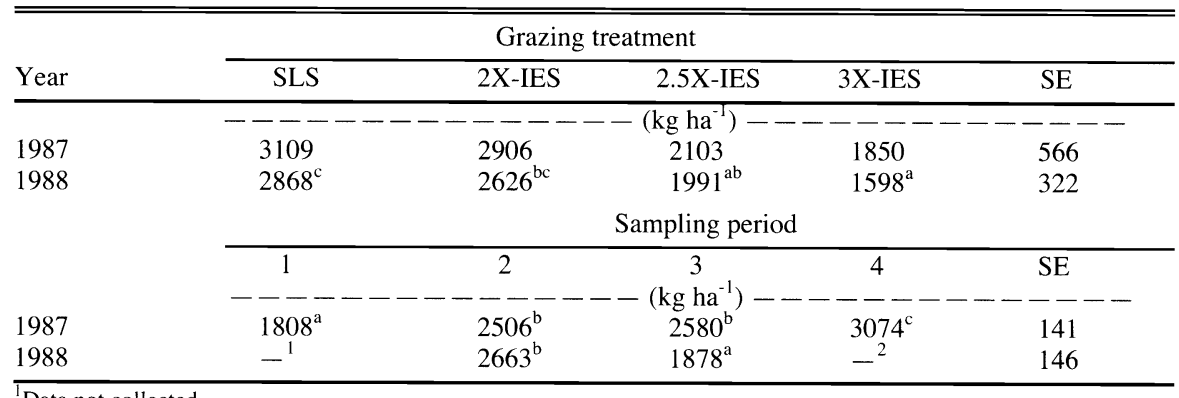

${ }^{\mathrm{T}}$ Data not collected.

${ }^{2}$ Livestock removed from intensive-early stocking treatments before fourth sampling period.

${ }^{\text {abc }}$ Means within a row lacking a common superscript differ $(P<0.10)$.

Table 3. Herbage availability, dietary nutrient density, and daily forage intake by steers grazing shortgrass plains during each sampling period of the last half of the season-long stocking grazing season.

\begin{tabular}{|c|c|c|c|c|c|c|c|c|}
\hline \multirow[b]{2}{*}{ Variable } & \multicolumn{4}{|c|}{1987} & \multicolumn{4}{|c|}{1988} \\
\hline & 5 Aug. ${ }^{1}$ & 2 Sep. & 30 Sep. & SE & $13 \mathrm{Jul}$. & 3 Aug. & 31 Aug. & SE \\
\hline & \multicolumn{8}{|c|}{$---------------\left(\mathrm{kg} \mathrm{ha}^{-1}\right)--------------$} \\
\hline Herbage availability & $3524^{\mathrm{b}}$ & $3465^{\mathrm{b}}$ & $3141^{\mathrm{a}}$ & 102 & 2033 & 1754 & 1872 & 127 \\
\hline Crude protein & $9.34^{\mathrm{b}}$ & $10.40^{\mathrm{b}}$ & $6.95^{\mathrm{a}}$ & 0.58 & $9.19^{\mathrm{a}}$ & $13.72^{\mathrm{b}}$ & $9.85^{\mathrm{a}}$ & $\overline{0.34}$ \\
\hline Neutral detergent fiber & 72.3 & 73.2 & 76.1 & 3.92 & 70.9 & 69.1 & 67.8 & 1.13 \\
\hline Acid detergent fiber & 38.4 & 39.2 & 42.9 & 2.57 & $39.9^{\mathrm{b}}$ & $37.9^{\mathrm{ab}}$ & $36.6^{\mathrm{a}}$ & 1.00 \\
\hline Acid detergent lignin & 5.89 & 6.04 & 6.64 & 0.65 & $5.53^{b}$ & $3.76^{\mathrm{a}}$ & $4.45^{\mathrm{a}}$ & 0.34 \\
\hline Hemicellulose & 33.8 & 34.0 & 33.2 & 1.74 & 31.1 & 31.2 & 31.3 & 1.36 \\
\hline Cellulose & 29.0 & 30.2 & 31.3 & 1.88 & $31.75^{\mathrm{b}}$ & $30.25^{\mathrm{ab}}$ & $29.48^{\mathrm{a}}$ & 0.54 \\
\hline \multirow[t]{2}{*}{ Digestibility } & 32.8 & 47.3 & 30.8 & 6.89 & 43.9 & 46.1 & 60.1 & 6.81 \\
\hline & \multicolumn{8}{|c|}{$---------\left(\%(\mathrm{OM})\right.$ of body weight day $\left.{ }^{-1}\right)--------$} \\
\hline Forage intake & $1.31^{\mathrm{a}}$ & $1.65^{\mathrm{b}}$ & $1.64^{\mathrm{b}}$ & 0.11 & 1.59 & 1.13 & 1.60 & 0.21 \\
\hline Fecal output & $0.864^{\mathrm{a}}$ & $0.862^{\mathrm{a}}$ & $1.130^{\mathrm{b}}$ & 0.071 & $0.826^{\mathrm{b}}$ & $0.592^{\mathrm{a}}$ & $0.638^{\mathrm{a}}$ & 0.025 \\
\hline
\end{tabular}

${ }^{1}$ Median date of each sampling period

${ }^{\mathrm{ab}}$ Means within a row and year lacking a common superscript differ $(\mathrm{P}<0.10)$.

et al. (1973) reported that dietary crude protein was similar among low and high grazing intensities. Likewise, Malechek (1984) indicated dietary crude protein was similar among low and high grazing intensities in a review of 4 studies on arid rangelands in Utah. These were in contrast with our results wherein crude protein was higher under some intensive-early stocking treatments late in the intensive-early stocking grazing season of 1987 , and inversely related to stocking density during 1988. Perhaps the additive influences of grazing treatment and drought conditions during 1988 reduced herbage availability below the point that would allow adequate selectivity. Wallace et al. (1972), Vavra et al (1973), and McCollum et al. (1985) all reported crude protein declined as the growing season progressed and forage matured. Generally, we found a similar response, except when only seasonlong stocking was stocked in 1988. Apparently, the lapse in drought conditions during July 1988 (Fig. 1) allowed a spurt of growth by the warm-season short- grasses: buffalograss and blue grama. Blue grama does not have a smooth growth curve, and actually grows in spurts, anytime moisture is available during the growing season (Bement 1969). We observed that buffalograss follows the same pattern. This weather-event driven improvement in forage conditions likely caused the rebound in dietary crude protein under season-long stocking during that period.

During 1987, NDF, ADL, hemicellulose, and cellulose responded $(\mathrm{P}=0.06$, $0.10,0.01$, and 0.01 , respectively), and ADF tended to respond $(\mathrm{P}=0.11)$ to grazing treatment (Table 4). In general, these cell wall constituents increased in the diet as stocking rate increased. The exception was cellulose, which was lower in diets of steers grazing double-stocked- and triplestocked-intensive-early stocking than steers grazing season-long stocking and $2.5 \mathrm{X}$-intensive-early stocking. During 1988 , none of the cell wall constituents responded to grazing treatment $(\mathrm{P}>0.29$, Table 4), but ADF and ADL displayed 
Table 4. Dietary nutrient density and daily forage intake by steers grazing shortgrass plains under season-long stocking (SLS) or intensive early stocking (IES) at 2, 2.5, or 3 times the stocking density of SLS (2X, 2.5X, or 3X, respectively) during each of 2 years.

\begin{tabular}{|c|c|c|c|c|c|c|c|c|c|c|}
\hline \multirow[b]{2}{*}{ Variable } & \multicolumn{4}{|c|}{1987} & \multirow[b]{2}{*}{$\mathrm{SE}$} & \multicolumn{5}{|c|}{1988} \\
\hline & SLS & 2X-IES & 2.5X-IES & $3 \mathrm{X}-\mathrm{IES}$ & & SLS & 2X-IES & 2.5X-IES & $3 \mathrm{X}-\mathrm{IES}$ & SE \\
\hline & & \multicolumn{9}{|c|}{ 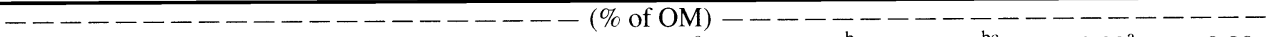 } \\
\hline Crude protein & 10.84 & 12.77 & 10.88 & 11.76 & 0.96 & $10.72^{\mathrm{c}}$ & $9.93^{b}$ & $10.52^{\mathrm{bc}}$ & $8.90^{\mathrm{a}}$ & 0.28 \\
\hline Neutral detergent fiber & $69.55^{\mathrm{ab}}$ & $68.53^{\mathrm{a}}$ & $72.42^{\mathrm{c}}$ & $71.40^{\mathrm{bc}}$ & 0.85 & 67.2 & 68.8 & 67.4 & 69.3 & 1.04 \\
\hline Acid detergent fiber & $36.25^{\mathrm{de}}$ & $34.98^{\mathrm{d}}$ & $37.46^{\mathrm{e}}$ & $36.24^{\mathrm{de}}$ & 0.64 & 35.3 & 37.9 & 35.9 & 38.0 & 2.04 \\
\hline Acid detergent lignin & $4.77^{\mathrm{a}}$ & $5.22^{\mathrm{b}}$ & $5.20^{\mathrm{b}}$ & $5.03^{\mathrm{ab}}$ & 0.13 & 5.02 & 5.80 & 5.42 & 5.81 & 0.57 \\
\hline Hemicellulose & $33.31^{\mathrm{a}}$ & $33.54^{\mathrm{a}}$ & $34.96^{\mathrm{b}}$ & $35.16^{\mathrm{b}}$ & 0.27 & 31.9 & 30.8 & 31.5 & 31.3 & 1.50 \\
\hline Cellulose & $30.20^{\mathrm{b}}$ & $27.65^{\mathrm{a}}$ & $30.52^{\mathrm{b}}$ & $28.96^{\mathrm{a}}$ & 0.37 & 27.6 & 29.5 & 27.8 & 28.9 & 1.20 \\
\hline \multirow[t]{2}{*}{ Digestibility } & 51.7 & 46.2 & 49.6 & 49.9 & 2.2 & 64.9 & 56.0 & 57.7 & 55.1 & 2.9 \\
\hline & & \multicolumn{9}{|c|}{$--------------\left(\%(\mathrm{OM})\right.$ of body weight $\left.\mathrm{day}^{-1}\right)--------------$} \\
\hline Forage intake & 1.11 & 1.18 & 1.20 & 1.23 & 0.17 & 1.87 & 1.73 & 1.90 & 1.76 & 0.22 \\
\hline Fecal output & 0.547 & 0.618 & 0.609 & 0.594 & 0.067 & 0.661 & 0.754 & 0.788 & 0.777 & 0.047 \\
\hline
\end{tabular}

${ }^{\mathrm{abc}}$ Means within a row and year lacking a common superscript differ $(\mathrm{P}<0.10)$.

${ }^{\mathrm{de}}$ Means within a row and year lacking a common superscript tend to differ $(\mathrm{P}=0.11)$.

grazing treatment $X$ sampling period interactions $(\mathrm{P}=0.08$ and 0.07 , respectively, Table 6). Acid detergent fiber was higher under triple-stocked-intensive-early stocking than the lower stocking densities during the first sampling period, but was similar across grazing treatments during the remaining sampling periods. Acid detergent lignin was similar among grazing treatments during the first 2 sampling periods, but varied during the final period, being lower for $2.5 \mathrm{X}$-intensive-early stocking than triple-stocked-intensiveearly stocking, with season-long stocking and double-stocked-intensive-early stocking similar and intermediate to other grazing treatments. Overall, cell-wall components generally increased in steer diets as grazing intensity increased, indicating that increased grazing pressure (more animal units per amount of available herbage) reduced the steers' ability to graze selectively, forcing them to consume herbage that was more mature. Wallace et al. (1972), Vavra et al. (1973), and McCollum et al. (1985) reported similar values for NDF and cellulose, but slightly higher values for ADF and lignin. These authors all oven dried their fistula samples, which causes formation of artifact lignin, thus artificially elevating ADF and lignin values (Burritt et al. 1988). Vavra et al. (1973) reported that ADF increased with grazing intensity during some sampling periods, but did not respond consistently, which was similar to our observations. Inconsistency in steer diet response to grazing intensity in all studies may result from the temporally dynamic nature of herbage availability and quality response to grazing treatments, weather events, and their interaction. For example, precipitation events may sometimes induce growth in all grazing treatments, allowing steers in all grazing treatments to be selective, but at other times, high quality forage may be depleted in treatments with high grazing intensity, or perhaps sometimes these treatments cannot respond to precipitation events because of shifts in vegetation composition or reductions in plant vigor. Vavra et al. (1973) also found that lignin did not respond to grazing intensity, in contrast to our results throughout 1987 and during the final sampling period in 1988. Malechek (1984) indicated that dietary lignin increased with grazing intensity in the 4 grazing studies conducted in Utah. Vavra et al. (1973) and Malechek (1984) reported mixed effects of grazing intensity on dietary cellulose, and Malechek (1984) suggested this was dependent upon changes among life forms of vegetation in the botanical composition of the diet.

During 1987, NDF, ADF, ADL, and cellulose increased as the intensive-early stocking grazing season progressed $(\mathrm{P}<$ 0.01 for NDF, ADF, and ADL, and $=0.05$ for cellulose, Table 5). None of these cell wall constituents changed during the remainder of the season-long stocking season after the intensive-early stocking season had ended ( $P>0.22$, Table 3 ). During 1988, NDF, ADF, hemicellulose, and cellulose varied across sampling periods $(\mathrm{P}=$ $0.04,<0.01,=0.06$, and $<0.01$, respectively, Table 5). Responses varied among the cell wall constituents that did not display an interaction with grazing treatment. Neutral detergent fiber increased during May and decreased in June, hemicellulose decreased in June from similar levels during both May sampling periods, and cellu-

Table 5. Dietary nutrient density and daily forage intake by steers grazing shortgrass plains during each sampling period during each of 2 years.

\begin{tabular}{|c|c|c|c|c|c|c|c|c|c|}
\hline \multirow[b]{2}{*}{ Variable } & \multicolumn{5}{|c|}{1987} & \multicolumn{4}{|c|}{1988} \\
\hline & 15 May $^{1}$ & 6 Jun. & 24 Jun. & 8 Jul. & SE & 4 May & 25 May & 15 Jun. & SE \\
\hline $\begin{array}{l}\text { Crude protein } \\
\text { Neutral detergent fiber } \\
\text { Acid detergent fiber } \\
\text { Acid detergent lignin } \\
\text { Hemicellulose } \\
\text { Cellulose } \\
\text { Digestibility }\end{array}$ & $\begin{array}{c}13.83^{\mathrm{c}} \\
66.0^{\mathrm{a}} \\
32.88^{\mathrm{a}} \\
4.26^{\mathrm{a}} \\
33.13 \\
27.30^{\mathrm{a}} \\
-^{2}\end{array}$ & $\begin{array}{l}10.41^{\mathrm{a}} \\
71.3^{\mathrm{b}} \\
36.33^{\mathrm{b}} \\
5.31^{\mathrm{b}} \\
34.98 \\
28.86^{\mathrm{ab}} \\
52.4\end{array}$ & $\begin{array}{l}10.48^{\mathrm{a}} \\
71.6^{\mathrm{b}} \\
37.56^{\mathrm{bc}} \\
5.28^{\mathrm{b}} \\
34.00 \\
30.13^{\mathrm{b}} \\
51.4\end{array}$ & $\begin{array}{c}11.53^{\mathrm{b}} \\
73.0^{\mathrm{b}} \\
38.16^{\mathrm{c}} \\
5.36^{\mathrm{b}} \\
34.87 \\
30.02^{\mathrm{b}} \\
44.2\end{array}$ & $\begin{array}{l}\% \text { of } \mathrm{O} \\
0.59 \\
1.50 \\
0.73 \\
0.25 \\
0.95 \\
0.99 \\
4.9\end{array}$ & $\begin{array}{l}12.31^{\mathrm{b}} \\
66.7^{\mathrm{a}} \\
34.53^{\mathrm{a}} \\
5.42 \\
32.17^{\mathrm{b}} \\
25.96^{\mathrm{a}} \\
62.5^{\mathrm{b}}\end{array}$ & $\begin{array}{c}9.19^{\mathrm{a}} \\
70.1^{\mathrm{b}} \\
38.09^{\mathrm{b}} \\
5.69 \\
31.96^{\mathrm{b}} \\
29.89^{\mathrm{b}} \\
58.5^{\mathrm{ab}}\end{array}$ & $\begin{array}{c}8.50^{\mathrm{a}} \\
67.8^{\mathrm{a}} \\
37.78^{\mathrm{b}} \\
5.43 \\
30.02^{\mathrm{a}} \\
29.43^{\mathrm{b}} \\
54.4^{\mathrm{a}}\end{array}$ & $\begin{array}{l}-\overline{0.51} \\
1.09 \\
0.57 \\
0.16 \\
0.84 \\
0.84 \\
2.6\end{array}$ \\
\hline $\begin{array}{l}\text { Forage intake } \\
\text { Fecal output }\end{array}$ & $\begin{array}{l}-\frac{-}{2}-- \\
-{ }^{2}\end{array}$ & $\begin{array}{l}1.03 \\
0.484^{\mathrm{a}}\end{array}$ & $\begin{array}{l}--1.21 \\
0.575^{\mathrm{b}}\end{array}$ & $\begin{array}{l}1.31 \\
0.718^{\mathrm{c}}\end{array}$ & $\begin{array}{l}\text { 1) of bc } \\
0.12 \\
0.043\end{array}$ & $\begin{array}{c}\left.\text { ght day }{ }^{-1}\right) \\
1.63^{\mathrm{a}} \\
0.597^{\mathrm{a}}\end{array}$ & $\begin{array}{c}1.78^{\mathrm{a}} \\
0.736^{\mathrm{b}}\end{array}$ & $\begin{array}{l}2.03^{\mathrm{b}} \\
0.902^{\mathrm{c}}\end{array}$ & $\begin{array}{l}---1 \\
0.11 \\
0.030\end{array}$ \\
\hline
\end{tabular}

Median date of each sampling period

${ }_{\text {Fbc }}^{2}$ Feces not collected during this sampling period.

${ }^{\mathrm{abc}}$ Means within a row and year lacking a common superscript differ $(\mathrm{P}<0.10)$. 
Table 6. Nutritional responses to grazing treatment $\times$ sampling period interactions.

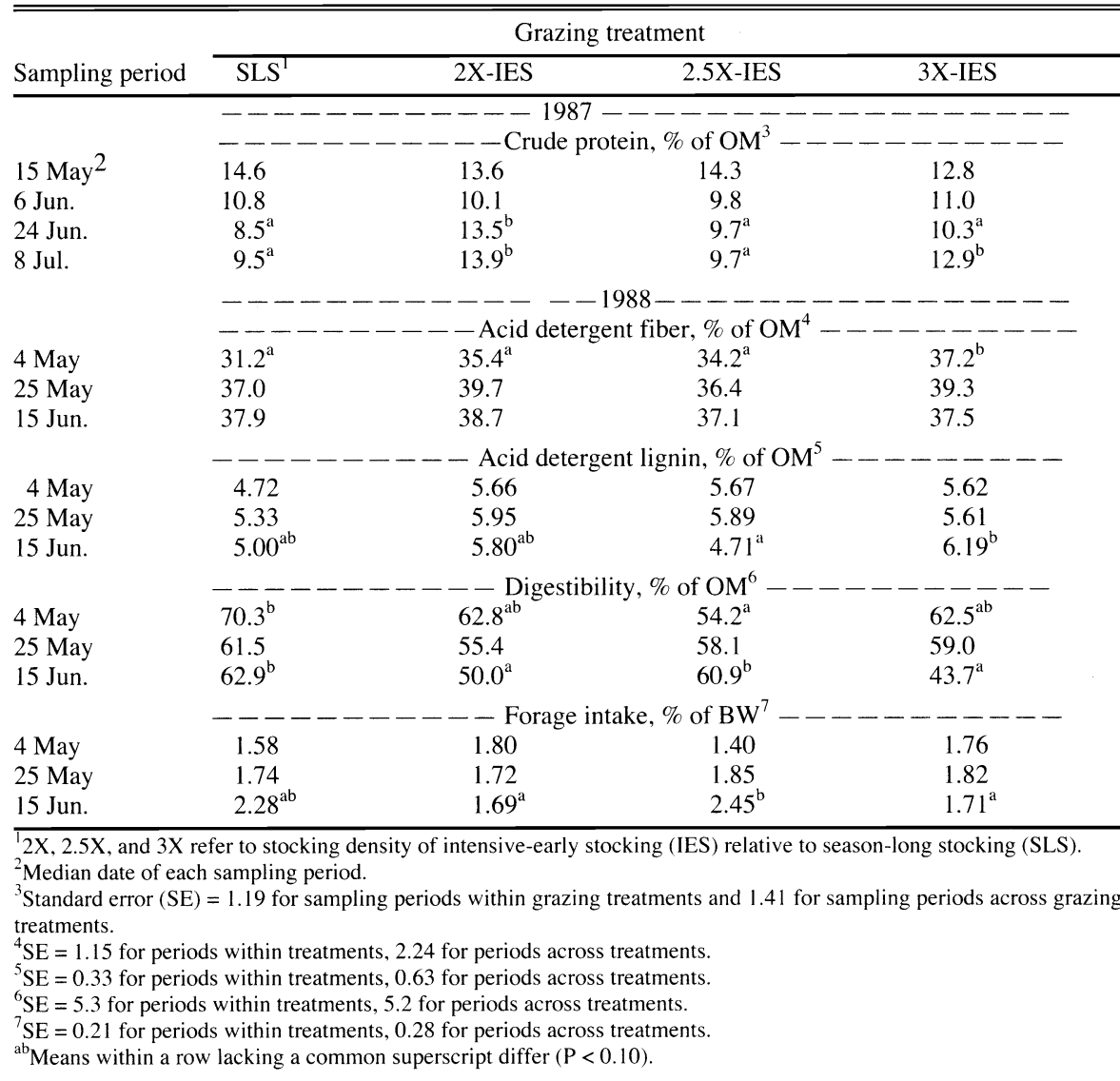

lose increased in May but did not change in June. Acid detergent fiber, ADL, and cellulose decreased across time during the last half of the season-long stocking grazing season $(\mathrm{P}=0.02,0.10$, and $<0.01$, respectively, Table 3 ). Wallace et al. (1972), Vavra et al (1973), and McCollum et al. (1985) reported that cell wall components generally increased as vegetation matured. The only exceptions were that Vavra et al. (1973) reported that cellulose was unaffected by maturity, and McCollum et al. (1985) reported that NDF decreased with maturity. The latter authors attributed this to increased forbs in the diet as the growing season progressed. Our results during 1987 fit the expectation that cell walls increase as plants mature. Variable results during 1988 were probably the result of spurts of new growth following precipitation events during the drought, as described previously.

Digestibility did not respond to the grazing treatment main effect during 1987 or 1988 ( $\mathrm{P}=0.26$ and 0.12 , Table 4), but displayed a grazing treatment $X$ sampling period interaction during $1988(P=0.10$, Table 6). During the early May sampling period of 1988 , digestibility was higher under season-long stocking than $2.5 \mathrm{X}$ - intensive-early stocking, with doublestocked- and triple-stocked-intensive-early stocking being intermediate and similar to all treatments. This relationship among treatments changed in late May, with no difference among grazing treatments, and changed again in June, with season-long stocking and $2.5 \mathrm{X}$-intensive-early stocking being similar and higher than doublestocked and triple-stocked-intensive-early stocking, which were similar. Digestibility was similar to that reported by Wallace et al. (1972), Vavra et al. (1973), Malechek (1984), and McCollum et al. (1985) for diets collected during the growing season. Vavra et al. (1973) reported small and inconsistent differences in in vitro dry matter digestibility among grazing intensities, with digestibility being greater under lower grazing intensity when differences existed. Malechek (1984) observed that digestibility generally was depressed by heavy grazing in the 4 Utah studies. He further indicated that a small depression in digestibility could severely impact animal performance because of its concomitant influence on forage intake. It was surprising that we did not detect depressed digestibility as stocking density increased in light of negative changes observed in dietary chemical composition. However, the standard error of treatment means was larger for digestibility than chemical components during both years (Table 4). Thus, high variability made detection of differences among treatment means difficult.

Digestibility did not vary across sampling periods during $1987(\mathrm{P}=0.25$, Table $5)$, but declined as the season progressed during $1988(\mathrm{P}=0.04)$. During both years, digestibility was similar among sampling periods during the last half of the season under season-long stocking $(\mathrm{P}>0.16$, Table 3). Wallace et al. (1972) and McCollum et al. (1985) both reported that digestibility declined as vegetation matured, and Vavra et al. (1973) reported that digestibility responded inconsistently as the grazing season progressed, but the general tendency was for digestibility to decrease as the season progressed. Digestibility would be expected to decline as crude protein declines and cell wall components increase in response to increasing plant maturity, but inconsistencies should be expected in shortgrass-dominated vegetation types wherein spurts of growth can increase diet quality, as previously discussed. Digestibility values were particularly low under season-long stocking during the early August and September sampling periods of 1987 . These were times when precipitation events had not occurred to initiate new growth, so the animals were selecting from typical, late-season mature herbage. Steers only gained $0.32 \mathrm{~kg} \mathrm{day}^{-1}$ during this period (Olson et al. 1993). However, when precipitation occurred late in the season-long stocking grazing season of 1988, digestibility values were higher. As a result, steers gained 0.47 $\mathrm{kg} \mathrm{day}^{-1}$ during this same period in 1988 (Olson et al. 1993).

Forage intake did not respond to the grazing treatment main effect during either year $(\mathrm{P}>0.84$, Table 4$)$, but displayed a grazing treatment by sampling period interaction during $1988(\mathrm{P}=0.04$, Table $6)$. In this interaction, forage intake did not respond to grazing treatments during the first 2 sampling periods, but was lowest under double-stocked- and triple-stockedintensive-early stocking, highest under 2.5X-intensive-early stocking, and seasonlong stocking was intermediate and similar to all intensive-early stocking treatments during the final sampling period. Apparently, neither forage quality nor quantity differences among grazing treatments influenced forage intake, because neither digestibility nor fecal output $(\mathrm{P}>$ 0.20 , Table 4$)$ responded to grazing treatment. This was in contrast to Vavra et al. 
(1973) and Malechek (1984), who reported depression of forage intake at heavier grazing intensities. Depression of forage intake would be expected because increased grazing intensity reduces availability of forage, which in turn limits the animal's ability to select a nutritious diet and restricts its ability to consume to its ruminal capacity.

Forage intake did not vary with time during 1987 ( $\mathrm{P}=0.14$, Table 5), but increased as the season progressed during $1988(\mathrm{P}=0.02)$. Forage intake increased $(\mathrm{P}=0.03)$ during the last half of the season-long stocking season of 1987 (Table $3)$, but did not change $(\mathrm{P}=0.53)$ during this period in 1988. McCollum and Galyean (1985) found that intake declined as forage matured, and suggested it was limited by forage quality, because forage intake was related directly to digestibility. In their study, fecal output did not vary among sampling periods, which indicated their steers were able to eat to a constant rumen fill. In our study, forage intake responses generally were similar to fecal output responses, which increased during the intensive-early stocking grazing season of both years $(\mathrm{P}<0.02$, Table 5$)$ and the last half of the season-long stocking grazing season of $1987(\mathrm{P}<0.01$, Table $3)$, but decreased $(P<0.01)$ during the same period of 1988 . Therefore, forage intake appeared to be limited by quantity rather than quality of forage because differences in fecal output suggest an inability to eat to a constant rumen fill. This was not supported by seasonal changes in total herbage availability, though, which was not always proportional to fecal output (Tables 2, 3, and 5). However, it is impossible to ascertain what portions of total herbage were considered acceptable as forage by the cattle and how this may have affected their ability and desire to maintain rumen fill.

Steer ADG responded to grazing treatment $(P=0.01)$ and year $(P=0.07)$. Average daily gains were $0.80,0.63,0.55$, and $0.47 \mathrm{~kg} \mathrm{~d}^{-1}(\mathrm{SE}=0.068)$ for seasonlong stocking, double-stocked-, $2.5 \mathrm{X}$-, and triple-stocked-intensive-early stocking, respectively. Gain was greater under season-long stocking than all intensive-early stocking treatments and greater under double-stocked-intensive-early stocking than triple-stocked-intensive-early stocking, with $2.5 \mathrm{X}$-intensive-early stocking intermediate and similar to both other intensive-early stocking treatments. Vavra et al. (1973) also reported improved performance at lower grazing intensity. They attributed it to greater digestibility and its influence on forage intake. In this study, it appears that the influence of forage availability on quality of the diet selected and ability of the steers to maintain gastrointestinal fill and concomitant fecal output were influential in determining steer ADG.

Steer ADG was greater in 1987 than $1988(0.66,0.56$, and 0.01 for 1987,1988 , and SE, respectively). This difference was likely a response to drought conditions during 1988, despite the fact that we removed animals earlier than planned to avoid extreme forage shortages.

\section{Conclusions and Implications}

Inferior vegetation characteristics created by grazing shortgrass rangeland for 9 years at $2.5 \mathrm{X}$ - and triple-stocked-intensiveearly stocking decreased the quality of diets that steers selected during the final 2 years of the study. Collectively, these data supported our hypothesis that nutrient intake would decline at higher stocking rates of intensive-early stocking (2.5X- and triple-stocked-intensive-early stocking). Nutritional quality typically was similar among diets collected from season-long stocking and double-stocked-intensiveearly stocking. These results substantiated our previous conclusion (Olson et al. 1993) that intensive-early stocking can be sustained at the same stocking rate as seasonlong stocking, but cannot be sustained at higher stocking rates. Furthermore, dietary nutritional quality and forage intake did not decline dramatically during the latter half of the season-long stocking grazing season. This supported our previous evidence that this vegetation type is not as suited to intensive-early stocking as types that lose substantial nutritional value as they mature, such as tallgrass prairie. In fact, nutritional quality actually can be relatively high during late summer if precipitation events keep the shortgrasses green and actively growing.

\section{Literature Cited}

AOAC. 1984. Official Methods of Analysis ( $14^{\text {th }}$ Ed.). Assoc. of Official Anal. Chem, Washington, D.C.

Bement, R.E. 1969. A stocking-rate guide for beef production on blue-grama range. $\mathrm{J}$. Range Manage. 22:83-86.

Burritt, E.A., J.A. Pfister, and J.C. Malechek. 1988. Effect of drying method on the nutritive composition of esophageal fistula forage samples: Influence of maturity. J. Range Manage. $41: 346-349$.
Cochran, W.G. and G.M. Cox. 1957. Experimental designs. Wiley and Sons, New York, N.Y.

Cochran, R.C., E.S. Vanzant, and T. DelCurto. 1988. Evaluation of internal markers isolated by alkaline hydrogen peroxide incubation and acid detergent lignin extraction. J. Anim. Sci. 66:3245-3251.

Goering, H.K. and P.J. Van Soest. 1970. Forage fiber analysis (apparatus, reagents, procedures, and some applications). USDAARS Agr. Handb. 379. Washington, D.C.

Karl, M.G. and R.A. Nicholson. 1987. Evaluation of the forage-disk method in mixed-grass rangelands of Kansas. J. Range Manage. 40:467-471.

Launchbaugh, J.L. 1957. The effect of stocking rate on cattle gains and on native shortgrass vegetation in west-central Kansas. Kansas Agr. Exp. Sta. Bull. 394. Manhattan, Kan.

Malechek, J.C. 1984. Impacts of grazing intensity and specialized grazing systems on livestock response, p. 1129-1158. In: Developing Strategies for Rangeland Management. Westview Press, Boulder, Colo.

McCollum, F.T. and M.L. Galyean. 1985. Cattle grazing blue grama rangeland. II. Seasonal forage intake and digesta kinetics. J. Range Manage. 38:543-546.

McCollum, F.T., M.L. Galyean, L.J. Krysl, and J.D. Wallace. 1985. Cattle grazing blue grama rangeland. I. Seasonal diets and rumen fermentation. J. Range Manage. 38:539-543.

McCollum, F.T., R.L. Gillen, D.M. Engle, and G.W. Horn. 1990. Stocker cattle performance and vegetation response to intensiveearly stocking of Cross Timbers rangeland. J. Range Manage. 43:99-103.

Olson, K.C. and G.D. Sunvold. 1991. Predicting digestibility of mixed cool- and warm-season grass diets with internal markers. Proc. West. Sec. Amer. Soc. Anim. Sci. 42:197-200.

Olson, K.C., J.R. Brethour, and J.L. Launchbaugh. 1993. Shortgrass range vegetation and steer growth response to intensiveearly stocking. J. Range Manage. 46:127-132.

Owensby, C.E., R. Cochran, and E.F. Smith. 1988. Stocking rate effects on intensive-early stocked Flint Hills bluestem range. J. Range Manage. 41:483-487.

SAS. 1988. SAS/STAT ${ }^{\mathrm{TM}}$ User's Guide (Release 6.03). SAS Inst. Inc., Cary, N.C.

Sharrow, S.H. 1984. A simple disc meter for measurement of pasture height and forage bulk. J. Range Manage. 37:94-95.

Vavra, M., R.W. Rice, and R.E. Bement. 1973. Chemical composition of the diet, intake and gain of yearling cattle on different grazing intensities. J. Anim. Sci. 36:411-414.

Wallace, J.D., J.C. Free, and A.H. Denham. 1972. Seasonal changes in herbage and cattle diets on sandhill grassland. J. Range Manage. 25:100-104. 